\title{
Selective Inhibition of Spinal Cord Neurite Outgrowth and Cell Survival by the Eph Family Ligand Ephrin-A5
}

\author{
Yong Yue, ${ }^{1,2}$ Jianying Su, ${ }^{1}$ Douglas Pat Cerretti, ${ }^{3}$ Gary M. Fox, ${ }^{4}$ Shuqian Jing, ${ }^{4}$ and Renping Zhou ${ }^{1,2}$ \\ ${ }^{1}$ Laboratory for Cancer Research, College of Pharmacy, Rutgers University, Piscataway, New Jersey 08854, ${ }^{2}$ Department \\ of Neuroscience and Cell Biology, Robert Wood Johnson Medical School, Piscataway, New Jersey 08854, 3/mmunex \\ Research and Development Corporation, Seattle, Washington 98101, and ${ }^{4}$ Amgen, Incorporated, Thousand Oaks, \\ California 91320
}

\begin{abstract}
The Eph family tyrosine kinase receptors and their ligands, the ephrins, have been shown to play critical roles in cell migration, tissue morphogenesis, and axonal guidance in many different systems. However, their function in the spinal cord has not been examined carefully. We showed in this study that several Eph receptors, including EphA3, Eph A4, and Eph A5, are expressed in the ventral spinal cord in partially overlapping patterns, with EphA5 exhibiting the most widespread transcription in the entire ventral spinal cord during early development. Complementary to the receptor expression, a ligand of these receptors, ephrin-A5, is transcribed in the dorsal half of the spinal cord.
\end{abstract}

The Eph family receptor tyrosine kinases and their ligands, the ephrins, have been shown recently to play critical roles in the development of axonal connections (for review, see Harris and Holt, 1995; Tessier-Lavigne, 1995; Friedman and O'Leary, 1996; Drescher, 1997; Orioli and Klein, 1997; Flanagan and Vanderhaeghen, 1998; Zhou, 1998). It has been proposed that ephrins guide axons by repulsion via the interaction with their receptors. Recent evidence also indicates that they may cause degeneration of axons and neurons (Gao et al., 1999; Yue et al., 1999). The Eph family consists of at least 14 receptors and eight ligands (Zhou, 1998). All of the ligands are membrane-bound and can be divided into two subclasses according to the mechanism of membrane association. The ephrin-A subclass ligands are attached to the cell membrane by glycosyl phosphatidylinositol tail, whereas the ephrin-B ligands are anchored by transmembrane domains (Zhou, 1998). Accordingly, the receptors also can be divided into EphA and EphB subclasses, interacting respectively with the ephrin-A and B subgroup ligands.

Recent studies suggest that the Eph family also may play key roles in development of the spinal cord, because several members are expressed in this tissue during development (Kilpatrick et al., 1996; Ohta et al., 1996; Zhang et al., 1997). To define further the roles of Eph family molecules in the developing spinal cord, we investigated the expression of six of the eight known Eph-A subgroup receptors (EphA3-A8) and all five known ephrin-A

\footnotetext{
Received July 8, 1999; revised Sept. 3, 1999; accepted Sept. 3, 1999.

This research was funded by National Institutes of Health Grants NS36788 and DA11480 to R.Z. We acknowledge J. Flanagan for generously providing the EphrinA2-AP construct and A. K. Halladay for her assistance in statistical analysis.

Correspondence should be addressed to Dr. Renping Zhou, Laboratory for Cancer Research, 164 Frelinghusen Road, College of Pharmacy, Rutgers University, Piscataway, NJ 08854. E-mail: rzhou@rci.rutgers.edu.

Copyright (C) 1999 Society for Neuroscience 0270-6474/99/1910026-10\$05.00/0
}

Consistent with the spatial location of receptor expression, the ligand selectively inhibits neurite outgrowth and induces cell death of the ventral, but not the dorsal, spinal cord neurons. These observations suggest that interactions between the Eph family receptors and ligands exerts negative influences on ventral spinal cord neurons and thus may play important roles in regulating morphogenesis and axon guidance in the spinal cord.

Key words: Eph family receptors; ephrins; neurite outgrowth; spinal cord; apoptosis; in situ hybridization subgroup ligands (ephrin-A1-A5). We further examined the biological effects of the Eph ligands on spinal cord neurons in vitro. We report here that the Eph receptors (EphA3, A4, A5) and one of their ligands, ephrin-A5, are expressed in mutually exclusive patterns in the spinal cord, with the receptors in the ventral and the ligand in the dorsal regions, respectively. In addition, using in vitro culture assays, we show that ephrin-A5 inhibits neurite outgrowth of the receptor-positive ventral spinal cord neurons. We also observed that ephrin-A5 induced apoptosis of the ventral spinal neurons in vitro. These observations indicate that the interactions between ephrin-A5 and EphA receptors may contribute to spinal cord morphogenesis or circuitry formation by selectively regulating neurite outgrowth and cell survival of the ventral horn neurons.

\section{MATERIALS AND METHODS}

Animals and preparation of tissue sections for in situ hybridization. CD-1 mouse embryos (Charles River Laboratories, Wilmington, MA) of different gestation days (E11-E18) were used in in situ hybridization experiments. The day of vaginal plug occurrence was defined as embryonic day 1 (E1). At least three animals were investigated for each experimental group. Whole embryos were dissected under carbon dioxide anesthesia and frozen on dry ice powder. Coronal and sagittal sections of $16 \mu \mathrm{m}$ thickness were cut with a cryostat at $-23^{\circ} \mathrm{C}$ and mounted on slides coated with $2 \%$ triethoxy-3-aminopropyl saline (Sigma, St. Louis, MO). Then the slides were stored at $-80^{\circ} \mathrm{C}$ before use.

In situ hybridization. mRNA expression was examined by either $\left[{ }^{35} \mathrm{~S}\right]-$ labeled in vitro-transcribed riboprobes or end-labeled oligonucleotide probes as described (Zhang et al., 1996). EphA3 mRNA was detected with an oligonucleotide probe of 51 base pairs (bp) containing the $3^{\prime}$ mouse EphA3 coding region (5'-TCC AGG ACT TTA CAC TGG AAC TGG ACC ATT CTT AGA TTG TGT TTC TAG AGC-3'). This region has no significant homology to other Eph family receptors. EphA4 mRNA was detected with a riboprobe made from a $285 \mathrm{bp}$ mouse cDNA fragment derived from the $5^{\prime}$ coding region cloned in pBluescript SK plasmid. Antisense riboprobe was synthesized with T7 RNA polymerase 
for hybridization, and sense control probe was generated with SP6 RNA polymerase.

EphA5 mRNA was detected with a riboprobe of 373 bp derived from the region of a mouse cDNA encompassing the transmembrane domain (nucleotides 1445-1818; Zhou et al., 1994) cloned in pGEM4 plasmid. Antisense riboprobe was synthesized with SP6 RNA polymerase for hybridization, and sense riboprobe was generated with T7 RNA polymerase as a control.

To examine the expression of the ligands, we performed in situ hybridization analyses with probes of all five ephrin-A ligands. Only ephrin-A5 showed strong expression in the dorsal spinal cord. Ephrin-A5 mRNA was detected with a riboprobe made from a $0.7 \mathrm{~kb}$ human ephrin-A5 cDNA containing the full coding region in pBluescript $\mathrm{SK}^{-}$. Human ephrin-A5 shares $>90 \%$ sequence homology with mouse ephrin-A5 in the nucleotide level (Zhang et al., 1996). It has been shown previously that this probe hybridizes specifically to mouse ephrin-A5 and does not cross-react with other ephrins (Zhang et al., 1996). Antisense riboprobe was synthesized with T3 RNA polymerase and hydrolyzed in $0.2 \mathrm{M}$ carbonate buffer at $60^{\circ} \mathrm{C}$ for hybridization, and sense riboprobe was synthesized with T7 RNA polymerase and treated the same as control.

EphA5-AP and ephrin-A5-AP staining. The ligand-affinity probe (EphA5-AP), was constructed previously for detecting ephrin-A ligands (Gao et al., 1996). The construct was cotransfected into NIH 3 T3 cells with aminoglycoside phosphotransferase gene, which confers G418 resistance. Then the transfected cells were selected with $400 \mu \mathrm{g} / \mathrm{ml} \mathrm{G} 418$ (Life Technologies, Gaithersburg, MD). Tissue culture media from positive clones of EphA5-AP were used as probes to detect ligand expression. The receptor-affinity probe ephrin-A2-AP was generously provided by John G. Flanagan (Harvard Medical School, Boston, MA), and the fusion protein was prepared by transient expression in COS-7 cells. Staining of the cultured dorsal and ventral spinal cord neurons was done as described previously (Flanagan and Leder, 1990).

Coculture assay. Lumbar spinal cord neurons of E17 Sprague Dawley rat embryos (Charles River Laboratories) were dissected under microscope in PBS. Dissected tissues were dissociated with trituration to single-cell suspension and plated at a density of $5 \times 10^{5}$ cells/well in 12-well dishes previously seeded with a confluent monolayer of ephrinA5-expressing or control NIH 3T3 cells transfected with the vector. Neurons were cocultured in DMEM supplemented with fetal bovine serum $(10 \%)$, penicillin $(50 \mu \mathrm{g} / \mathrm{ml})$, and streptomycin $(50 \mu \mathrm{g} / \mathrm{ml})$. The cocultures were maintained for various periods of time and stained with a polyclonal anti-neuronal specific enolase (NSE) antibody (Polysciences, Warrington, PA) or a monoclonal anti-tau-1 antibody (Boehringer Mannheim, Indianapolis, IN). The number of neurons and the lengths of neurites were measured with a Zeiss Telaval 31 microscope.

Assay for purified ephrin-A5-Fc. To assay the effect of purified ephrinA5-Fc, we treated 12-well tissue culture dishes according to a procedure by Ohta et al. (1997) with modification. Briefly, the wells first were coated with poly-D-lysine $(100 \mu \mathrm{g} / \mathrm{ml})$ and laminin $(20 \mu \mathrm{g} / \mathrm{ml})$ sequentially for 1 $\mathrm{hr}$ each in $\mathrm{a} \mathrm{CO}_{2}$ incubator and then air-dried at room temperature for $1 \mathrm{hr}$. Next the wells were coated with purified ephrin-A5-Fc (100 ng for each well) either alone or cross-linked with anti-human IgG (500 ng for each well). The cross-linking was done by mixing $100 \mathrm{ng}$ of ephrinA5-Fc with $500 \mathrm{ng}$ of anti-human IgG in a total volume of $3 \mu \mathrm{l}$; the mixture was incubated at $37^{\circ} \mathrm{C}$ for $60 \mathrm{~min}$. Wells coated with anti-human $\mathrm{IgG}$ also were used as an additional control.

Dissected dorsal or ventral E17 rat lumbar spinal cord neurons were seeded in coated tissue culture wells $\left(5 \times 10^{5}\right.$ neurons/well $)$ and cultured for $48 \mathrm{hr}$ in serum-free medium containing 50\% Ham's F12, 50\% minimum essential medium (MEM), insulin $(25 \mu \mathrm{g} / \mathrm{ml})$, transferrin (100 $\mu \mathrm{g} / \mathrm{ml})$, D-glucose $(0.6 \%)$, putrescine $(60 \mu \mathrm{M})$, progesterone $(20 \mathrm{nM})$, L-glutamine $(146 \mathrm{mg} / \mathrm{ml})$, selenium (30 nM), penicillin $(50 \mu \mathrm{g} / \mathrm{ml})$, and streptomycin $(50 \mu \mathrm{g} / \mathrm{ml})$. The cultured neurons were stained with monoclonal anti-tau-1 antibody (Boehringer Mannheim).

Detection of apoptotic cells. E17 rat lumbar spinal cord neurons were cultured as described for $24 \mathrm{hr}$ and fixed with $4 \%$ paraformaldehyde in PBS, $\mathrm{pH} 7.4$, and then permeabilized with $0.1 \%$ Triton $\mathrm{X}-100 / 0.1 \%$ sodium citrate at $4^{\circ} \mathrm{C}$ for $2 \mathrm{~min}$. Then $200 \mu \mathrm{l}$ of terminal deoxynucleotidyl transferase-mediated dUTP nick end-labeling (TUNEL) reaction mixture was added to each well according to company specifications (Boehringer Mannheim) and was incubated for $60 \mathrm{~min}$ at $37^{\circ} \mathrm{C}$. Positively stained apoptotic cells were examined by fluorescence microscope.

\section{RESULTS}

\section{Region-specific expression of Eph receptors and ligands in the mouse spinal cord}

To examine the roles of Eph family receptors and ligands in the development of the mouse spinal cord, we investigated the expression of six EphA subgroup receptors, EphA3-A8, and all five ephrin-A subgroup ligands, ephrin-A1-A5, at the critical time of mouse spinal cord development by using in situ hybridization. EphA1 and A2 expression was not examined because they have not been shown to be transcribed at significant levels in the nervous system (Zhou, 1998). These studies showed that at least three EphA receptors, EphA3, A4 and A5, and one ligand, ephrin-A5, are expressed in the spinal cord. In the mouse embryos (E14-E18), EphA3 and EphA4 were expressed specifically in the medial and lateral motor column neurons, respectively (Fig. $1 A-C)$. EphA5 was found in the entire ventral horn, which includes both interneurons and motor neurons (Fig. 1D). A survey of the ephrin-A ligands showed that one ligand, ephrin-A5, showed high levels of expression in the dorsal spinal cord at E14 (Fig. 1E). The remaining four ephrin-A ligands had no or only low levels of expression in the spinal cord (data not shown). No significant differences were observed along different levels of the spinal cord.

\section{Dissection of dorsal and ventral spinal cord neurons}

To elucidate the contributions of the Eph family guidance molecules in the development of the spinal cord, we assayed the effects of ephrin-A5 on neurite growth and survival of neurons from the dorsal or ventral E17 rat lumbar spinal cord (equivalent to E16 in mouse). Rat E17 spinal cord was used because active axon targeting and interneuron cell death occur at approximately this time. Because the dorsal horn cells express high levels of ephrin-A5 and the ventral horn cells transcribe high levels of Eph receptors (these patterns of expression were maintained in E16 and E18 mouse spinal cord), the precision of dissection was determined by examining the expression of the ligand and receptors in dissected neurons. Neurons from properly dissected dorsal preparations should express primarily ephrin-A5, whereas neurons from the ventral preparations should express mostly the Eph receptor proteins. The expression of the ligand was assayed with EphA5-AP fusion protein, which contains the ligand-binding domain of the receptor linked in frame with human alkaline phosphatase (Zhang et al., 1996). EphA5-AP and similar constructs have been used widely to detect the expression of ephrin-A subclass ligands (Cheng et al., 1995; Gale et al., 1996; Flenniken et al., 1996; Zhang et al., 1996). Similarly, the expression of the Eph receptors was assayed with ephrin-A2-AP fusion protein, which contains ephrin-A2 fused to human alkaline phosphatase (Cheng et al., 1995). Because of the promiscuity of interaction between Eph receptors and ligands, ephrin-A2 binds to almost all EphA subclass receptors (Flanagan and Vanderhaeghan, 1998; Zhou, 1998) and should detect the expression of the three EphA receptors transcribed in the spinal cord.

Dissected dorsal and ventral lumbar rat spinal cord neurons were cultured in serum-free medium on poly-D-lysine/laminincoated 12-well dishes for $48 \mathrm{hr}$ and then stained with EphA5-AP or ephrin-A5-AP fusion proteins (see Materials and Methods for details). These analyses revealed that $76 \%$ of the dissected dorsal neurons had EphA5-AP-staining and only $13 \%$ of these neurons showed ephrin-A2-AP binding. In contrast, $\sim 81 \%$ of the dissected ventral neurons showed positive staining by ephrin-A2AP, and only $17 \%$ of these cells had positive staining for 

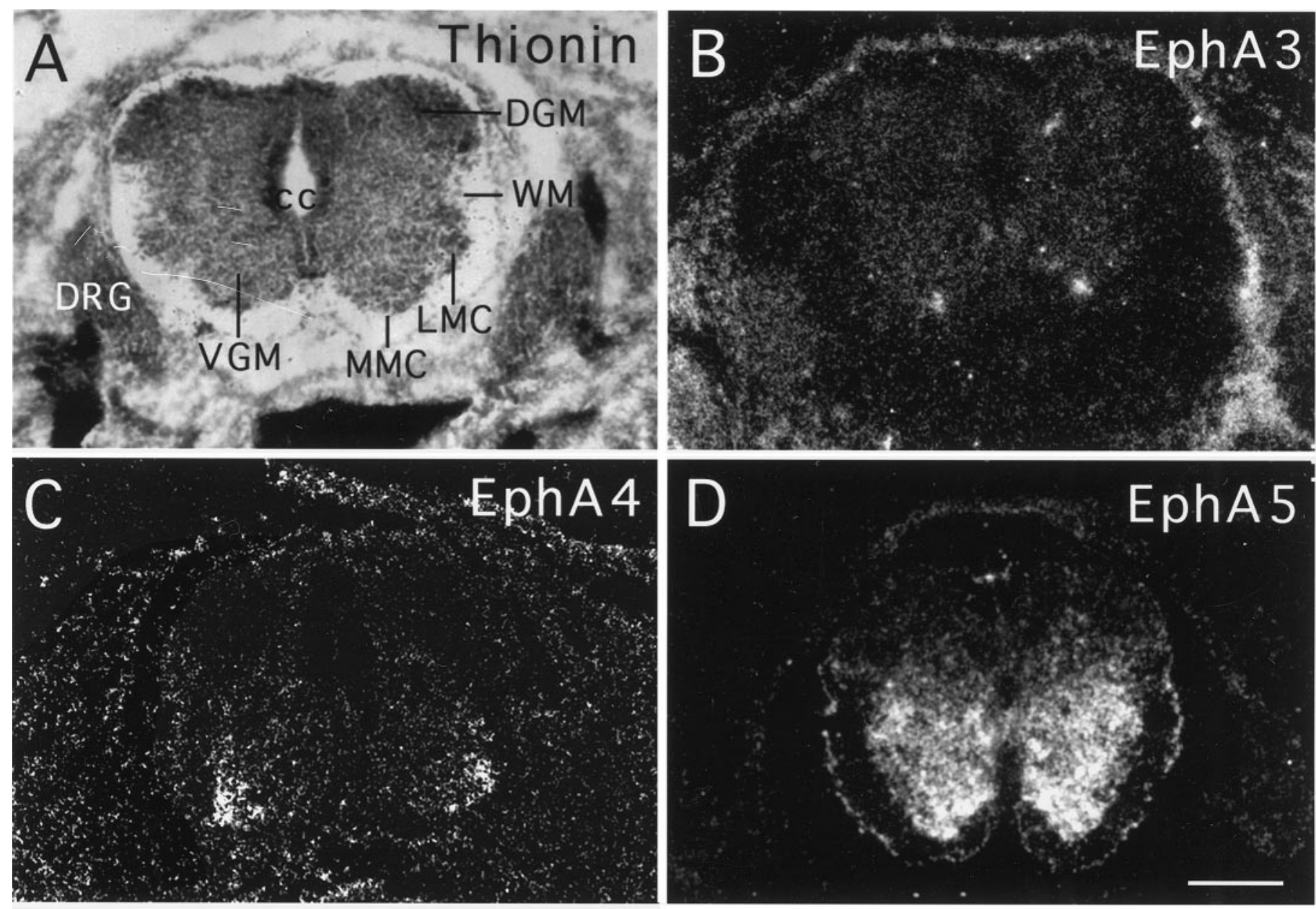

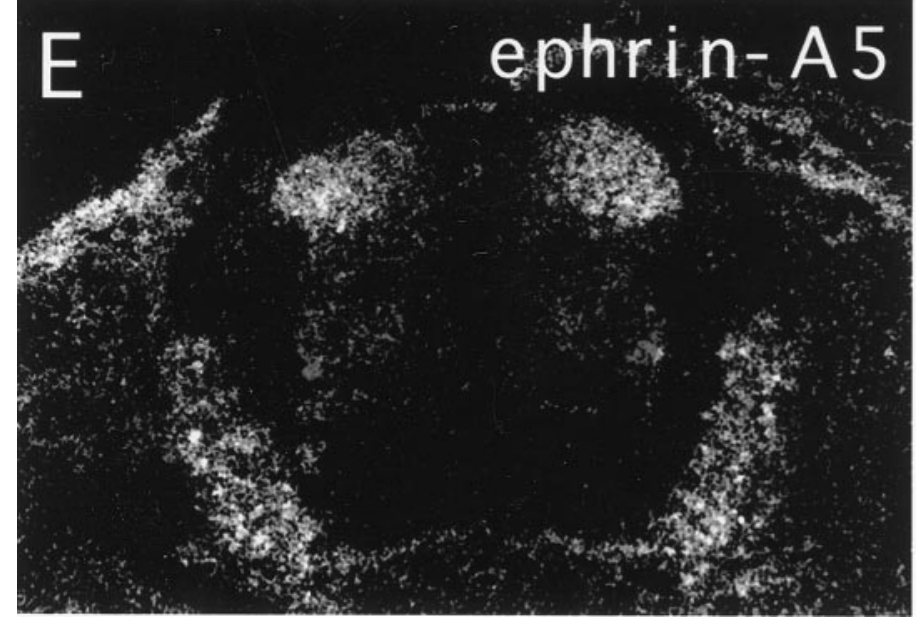

EphA5-AP (Fig. 2). These observations are consistent with the results from our in situ hybridization analysis that the dorsal neurons express ephrin-A5 and the ventral neurons transcribe Eph receptors, and indicate that our dissection is precise. Neurons from these dissections are mostly interneurons, because the motor neurons consist of only $\sim 7 \%$ of the total neuron population.

\section{Reduction of ventral spinal cord neurite length by ephrin-A5}

To examine the effects of ephrin-A5 on spinal cord neurite outgrowth and survival, we cocultured dorsal or ventral spinal
Figure 1. Complementary expression of the Eph family receptors and ligands in the developing lumbar spinal cord. $A$, Bright-field photomicrograph of a cross section of E14 mouse lumbar spinal cord counterstained with thionine. $B-E$, Dark-field photomicrographs of E14 lumbar spinal cord cross sections hybridized with antisense EphA3, EphA4, EphA5, and ephrin-A5 probes, respectively. The signals at the bottom part of $E$ are localized to the dorsal root ganglia. $D G M$, Dorsal gray matter; $D R G$, dorsal root ganglion; $L M C$, lateral motor column; $M M C$, medial motor column; $V G M$, ventral gray matter; $W M$, white matter. Scale bar, $180 \mathrm{~mm}$.

cord neurons with ephrin-A5-expressing cells or control cells transfected with the expression vector only. After $48 \mathrm{hr}$ of culture the neurons were identified by immunocytochemical staining with anti-neuron-specific enolase (NSE) antibody (Polysciences). These coculture assays showed that, whereas the ephrin-A5expressing cells had no significant effects on neurite outgrowth of the dorsal spinal cord neurons as compared with the control NIH 3 T3 cells (Fig. 3A,B), they greatly reduced the neurite length of the ventral spinal cord neurons (compare Figs. $3 C, D, 4 A$ ). Quantitative analyses revealed that the lengths of the ventral neurites cocultured with ephrin-A5-expressing cells were only $\sim 40 \%$ of 


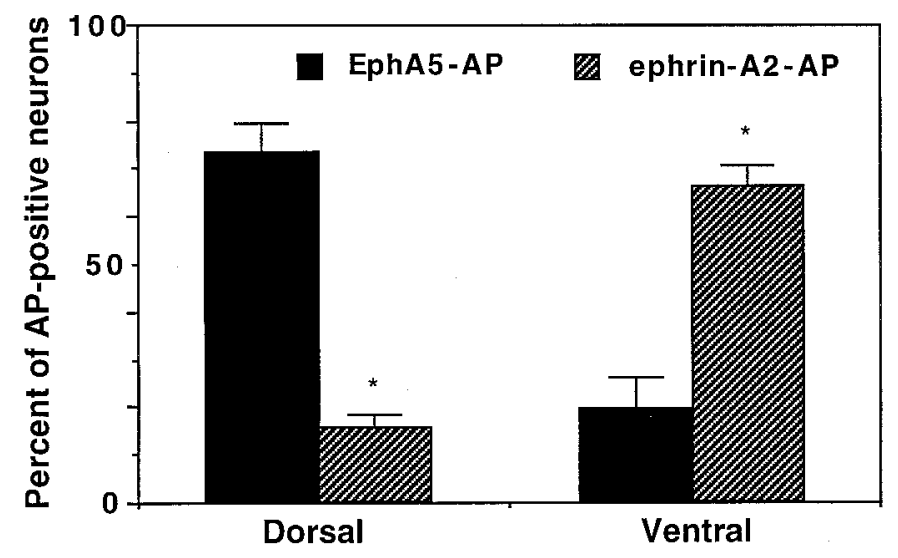

Figure 2. Dissection of dorsal and ventral spinal cord neurons. Neurons from the dorsal or ventral E17 rat lumbar spinal cord were plated on laminin-coated tissue culture wells and cultured for $48 \mathrm{hr}$. Then the neurons were stained with EphA5-AP or ephrin-A2-AP to detect ligand or receptor expression, respectively. ${ }^{*}$ Indicates that the differences are statistically significant ( $p<0.005$; Student's $t$ test).

those cocultured with the control cells (Fig. 4A). To ascertain whether this negative effect is attributable specifically to the expression of ephrin-A5, we studied the effect of ephrin-A5expressing cells in the presence of ephrin-A5-Fc and phosphatidylinositol phospholipase C (PI-PLC). Ephrin-A5-Fc has been shown to counteract the effect of membrane-bound ligands on axon guidance of retina ganglion neurons (Ciossek et al., 1998), whereas PI-PLC treatment releases the glycosyl phosphatidylinositolanchored ligand from the cell membrane and thus inactivates the ligand (Cheng et al., 1995). Ephrin-A5-Fc treatment increased the ventral neurite length cultured on ephrin-A5-expressing cells in a dose-dependent manner while having no effects on neurites cocultured with the control cells (see Figs. $3 E, F, 4 B$ ). A similar increase in neurite length was observed when PI-PLC was added in the coculture (Fig. 4C).

\section{Induction of ventral spinal cord cell death by ephrin-A5}

In addition to a significant reduction in neurite length in the presence of ephrin-A5, the cell density of NSE-positive ventral spinal cord neurons cocultured with ephrin-A5-expressing cells is only $\sim 58 \%$ of that cocultured with the control cells (Fig. 5). In contrast, no significant difference was found between the number of surviving dorsal spinal cord neurons cocultured with ephrinA5-expressing and control cells (Fig. 5).

To examine whether the cell loss was attributable to the lack of cell adhesion, we compared neuron numbers on ephrin-A5expressing and control cells at different culture times. If the ventral neurons fail to adhere to the ligand-expressing cells initially, we would expect a difference in neuron number soon after the establishment of the coculture. Contrary to this expectation, at $8 \mathrm{hr}$ of coculture the numbers of neurons on ephrin-A5expressing and control cells were indistinguishable (Fig. 5B). However, cell loss in ventral spinal cord coculture with the ligandexpressing cells became obvious by $36 \mathrm{hr}$, whereas few losses were observed when these neurons were cocultured with control cells (Fig. $5 B$ ). By the end of the $3 \mathrm{~d}$ culture period, $\sim 87 \%$ of dorsal neurons and $62.5 \%$ of ventral neurons survived in NIH 3T3 control culture. In contrast, $75 \%$ of the dorsal and $25 \%$ of the ventral neurons survived in the presence of membrane-attached ephrin-A5 (Fig. 5B), indicating that ephrin-A5 has only a minor effect on the dorsal neurons but significantly promoted cell loss of the ventral neurons. These results suggest that the cell loss is unlikely to be attributable to the lack of initial adhesion of ventral neurons to the ligand-expressing cells. Further, we analyzed the effect of the two reagents that interfere with ephrin function, PI-PLC and ephrin-A5-Fc. In the presence of both reagents the number of surviving ventral neurons increased in a dosedependent manner (Fig. 6). Inhibition of the ephrin effect on cell survival by PI-PLC and soluble ephrin-A5-Fc indicates that the effect is specifically attributable to ephrin-A5 expressed on the cell surface.

\section{Effects of cross-linked purified ephrin-A5-Fc}

To exclude further the possibility that the negative effects of ephrin-A5-expressing cells on ventral spinal neurons was related to the presence of unknown factors secreted by the cell lines, we examined the effect of ephrin-A5 in a cell-free system. Artificially cross-linked purified ephrins have been shown to activate the tyrosine kinase activity of Eph family receptors (Davis et al., 1994; Stein et al., 1998) and to inhibit the neurite outgrowth of motor neurons (Ohta et al., 1997). Purified ephrin-A5-Fc was tagged with human IgG-Fc region and could be cross-linked with anti-human IgG. Dorsal or ventral spinal cord neurons were cultured in tissue culture wells coated with the cross-linked ligand, anti-IgG alone, or un-cross-linked ligand alone. Neurons were cultured for $48 \mathrm{hr}$ in serum-free medium and stained with an anti-tau-1 monoclonal antibody. Similar to those observed in the coculture assays, no significant differences were found in either neurite length or the number of tau-positive dorsal neurons between cultures in wells coated with cross-linked ligand and controls (Fig. $7 A, B, E$ ). However, the neurite lengths of ventral neurons were much shorter in wells coated with cross-linked ligand than in wells coated with either IgG or uncross-linked ephrin-A5-Fc (Fig. 7C,D). Furthermore, the cell density of taupositive ventral neurons cultured on cross-linked ligand was significantly less $(56 \%)$ than that on either the uncross-linked ligand or the IgG control (Fig. $7 C-E$ ). Together with the coculture results, these data strongly suggest that ephrin-A5 reduces ventral neurite length and induces the loss of the ventral spinal cord neurons.

\section{Induction of apoptotic cell death by ephrin-A5}

The loss of the ventral neurons could be explained by apoptotic cell death induced by ephrin-A5. To examine this possibility, we labeled the cocultured neurons as well as neurons in the cell-free assays with the TUNEL staining, which has been used widely as an indicator for apoptotic cell death (Gavrieli et al., 1992). In both assays active ephrin-A5 had no effects on the number of TUNEL-positive cells in cultures of dorsal neurons (Fig. 8; data not shown). In contrast, the ligand significantly increased the number of TUNEL-positive cells in the ventral cultures (Fig. $8 C$; data not shown), indicating that ephrin-A5 specifically induced apoptotic cell death of ventral spinal cord neurons.

\section{DISCUSSION}

The current study has examined the role of the Eph family ligands and receptors in regulating the growth and survival of spinal cord neurons. Our analyses showed that several receptors of the EphA subclass, including EphA3, A4, and A5, were expressed in the ventral spinal cord in partially overlapping patterns during embryonic development. EphA3 and A4 were transcribed specifically in the medial and lateral motor columns, respectively. Eph-A5 

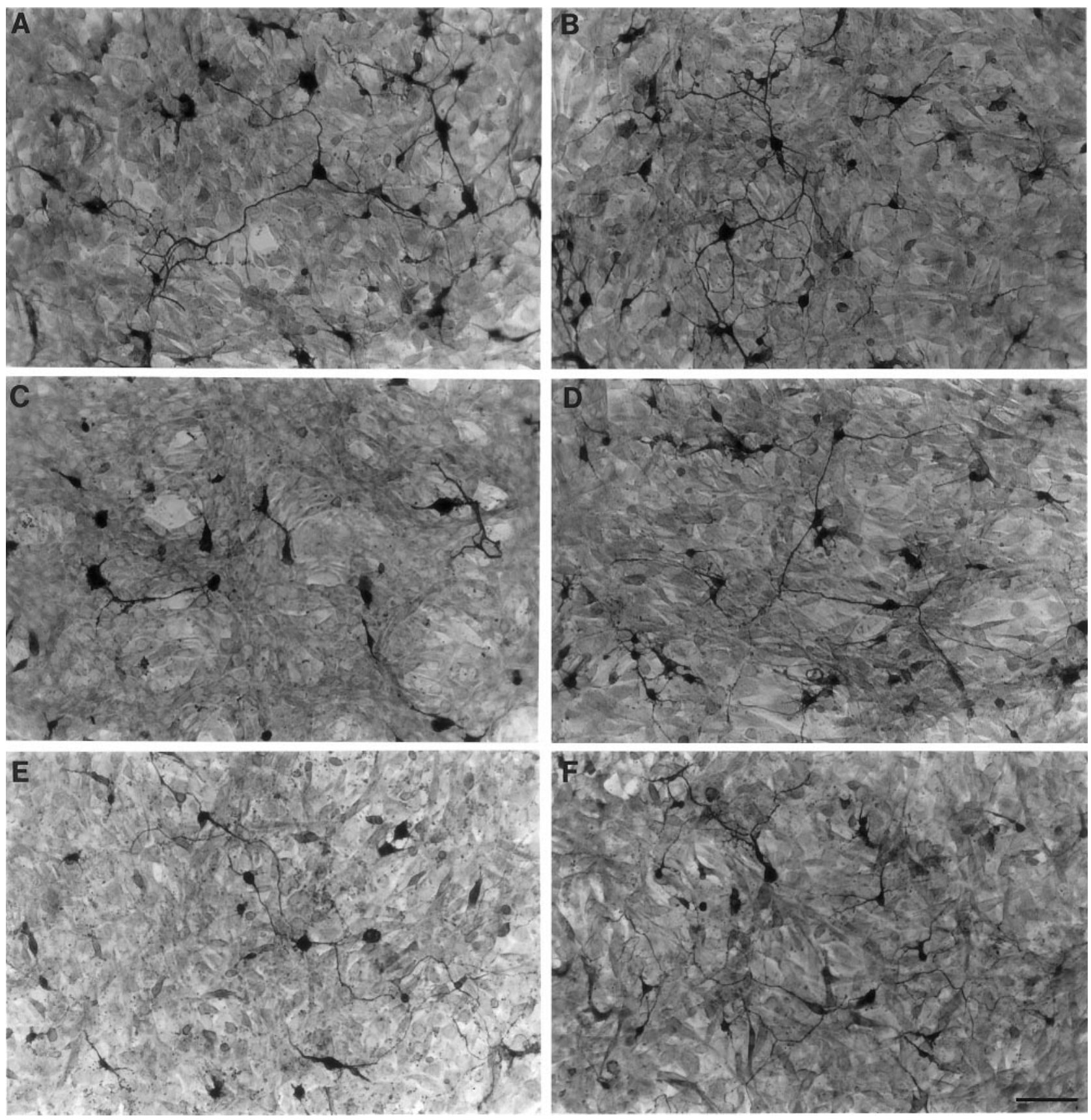

Figure 3. Ephrin-A5 reduces the neurite length of ventral spinal neurons. Dorsal or ventral E17 rat lumbar spinal cord neurons growing on a confluent monolayer of ephrin-A5-expressing cells were detected after $48 \mathrm{hr}$ of culture by immunocytochemical staining with anti-neuron-specific enolase antibody. Neurons and neurites are stained darkly, and the underlying fibroblasts show background staining. $A$, $B$, Dorsal spinal cord neurons plated on ephrin-A5-expressing or control cells, respectively. $C, D$, Ventral spinal cord neurons plated on ephrin-A5-expressing or control cells, respectively. $E$, $F$, Ventral spinal cord neurons plated on ephrin-A5-expressing or control cells, respectively, in the presence of $5 \mu \mathrm{g} / \mathrm{ml}$ purified uncross-linked ephrin-A5-Fc. Soluble uncross-linked ephrin-A5-Fc partially restored neurite outgrowth from the ventral neurons but showed no effects on neurons cocultured with control cells. Scale bar in $F, 40 \mu \mathrm{m}$.

exhibited more widespread expression in the entire ventral spinal cord. Complementing the expression of the receptors, a ligand of these receptors, ephrin-A5, was expressed in the dorsal half of the spinal cord. The specific expression of the receptors and ligands was demonstrated in both the mRNA, as revealed by using in situ hybridization, and the protein levels, as detected by using ligand-AP or receptor-AP fusion protein binding of dissociated neurons. These expression patterns are also consistent with the results of a previous study that used receptor-Fc fusion proteins
(Gale et al., 1996). We further demonstrated that, consistent with the spatial location of receptor expression, the ligand selectively inhibited neurite outgrowth of the ventral spinal cord neurons. In contrast, the ligand had no significant effect on the dorsal spinal neurons. In addition, our studies revealed that ephrin-A5 induced apoptotic cell death in vitro. The apoptotic activity of ephrin-A5 was also dependent on the presence of receptor expression. These observations suggest that the Eph family receptors and ligands may interact to regulate negatively the ventral spinal cord neu- 

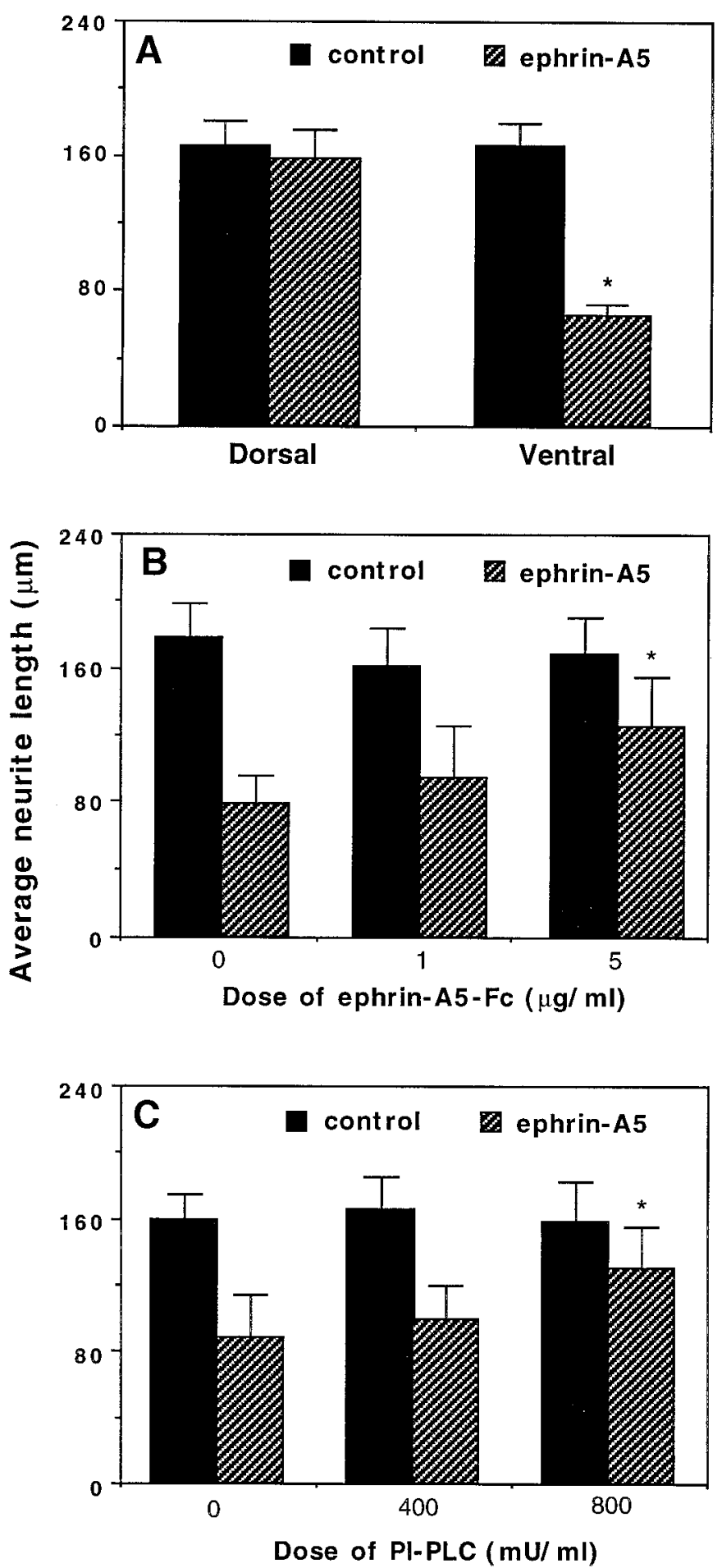

Figure 4. Quantitative analysis of ephrin-A5 effects on spinal cord neurite outgrowth. $A$, The lengths of ventral neurites are significantly shorter when cocultured with ephrin-A5-expressing cells than when cocultured with control cells. Data shown are the average length of neurites surveyed \pm SEM. ${ }^{*} p<0.05$; Student's $t$ test. $B, C$, The ephrin inhibitors ephrin-A5-Fc and PI-PLC partially restore the neurite outgrowth of ventral spinal cord neurons in a dose-dependent manner. ${ }^{*} p<0.001$; ANOVA. Control represents ventral spinal neurons grown on controltransfected NIH 3T3 cells. The ventral neurites are the longest under this condition. Soluble ephrin-A5-Fc does not alter neurite outgrowth significantly in the control cultures. In the absence of inhibitors the ventral neurites are the shortest on the ephrin-A5-expressing cells.

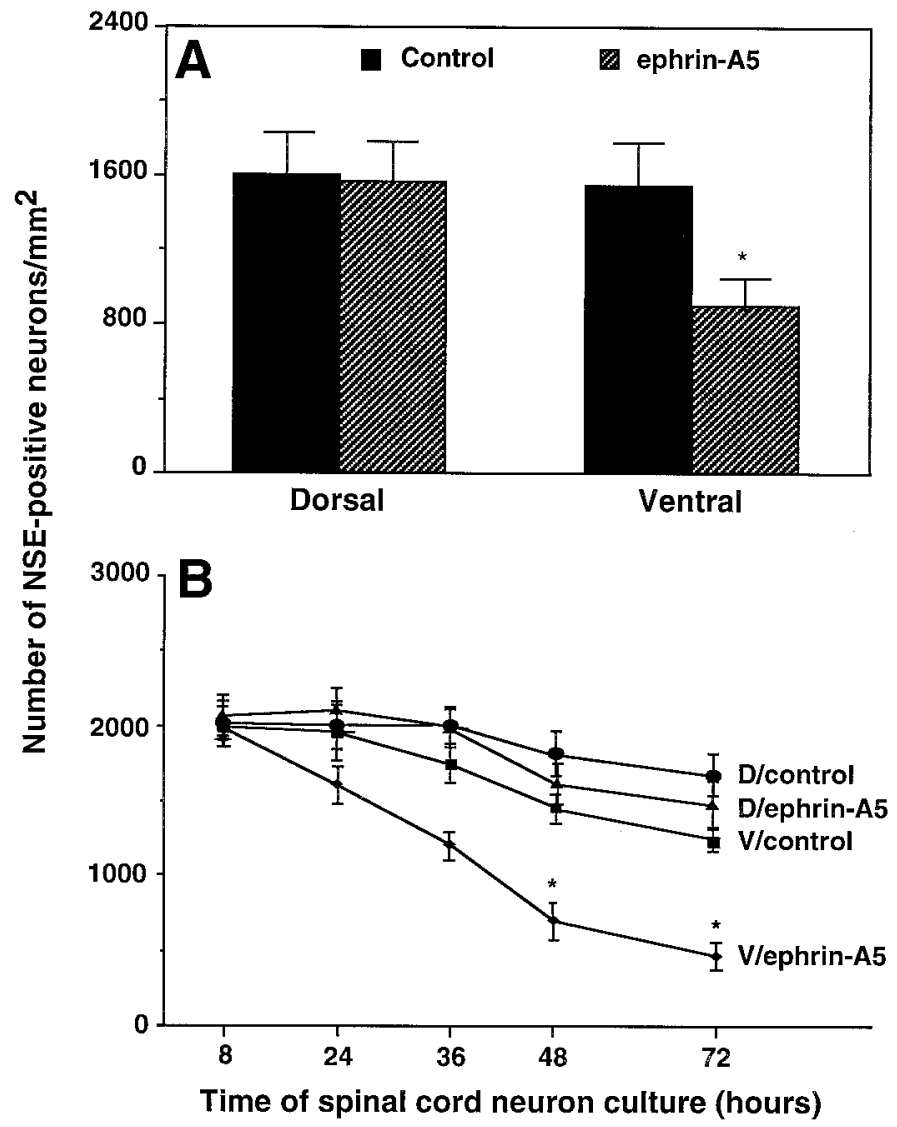

Figure 5. Quantitative analysis of ephrin-A5 effects on the survival of E17 rat ventral lumbar spinal cord neurons. $A$, Ephrin-A5 selectively induces cell loss of ventral spinal cord neurons. Ventral and dorsal spinal cord neurons were cocultured with a confluent monolayer of ephrin-A5expressing cells or control NIH $3 \mathrm{~T} 3$ cells for $48 \mathrm{hr}$ and then stained with anti-neuron-specific enolase antibody. Data shown are the average numbers of surviving neurons $/ \mathrm{mm}^{2} \pm$ SEM from six different assays. *Significant differences $(p<0.05$; Student's $t$ test $)$. $B$, Time course of ventral spinal cord neuron loss. Dorsal or ventral spinal cord neurons were cocultured with ephrin-A5 or control cells for various time periods and examined for survival by using immunocytochemical staining with antineuronal-specific enolase antibody. ${ }^{*}$ Significant differences $(p<0.001$; ANOVA). $D$, Dorsal spinal neurons; $V$, ventral spinal neurons.

rons specifically and thus contribute to the morphogenesis or the formation of neural circuitry in the spinal cord.

Roles of the Eph ligand and receptor expression in the spinal cord

The expression of Eph receptors in the spinal cord is highly restricted. EphA3 was transcribed primarily in the medial motor column, whereas Eph-A4 was detected mainly in the lateral motor column. These observations are consistent with previous studies showing that these two receptors are expressed in subsets of motor neurons (Kilpatrick et al., 1996; Ohta et al., 1996). EphA5, on the other hand, was transcribed in the entire ventral half of the spinal cord in both motor neurons and interneurons. Contrary to the receptor expression, ephrin-A5, a ligand of the Eph family that interacts with all three receptors (Flanagan and Vanderhaeghen, 1998; Zhou, 1998), was found at high levels in the dorsal spinal cord.

The significance of the Eph expression is not clear at the present. The complementary expression patterns suggest that the interaction between the ligands and receptors may play a role in 


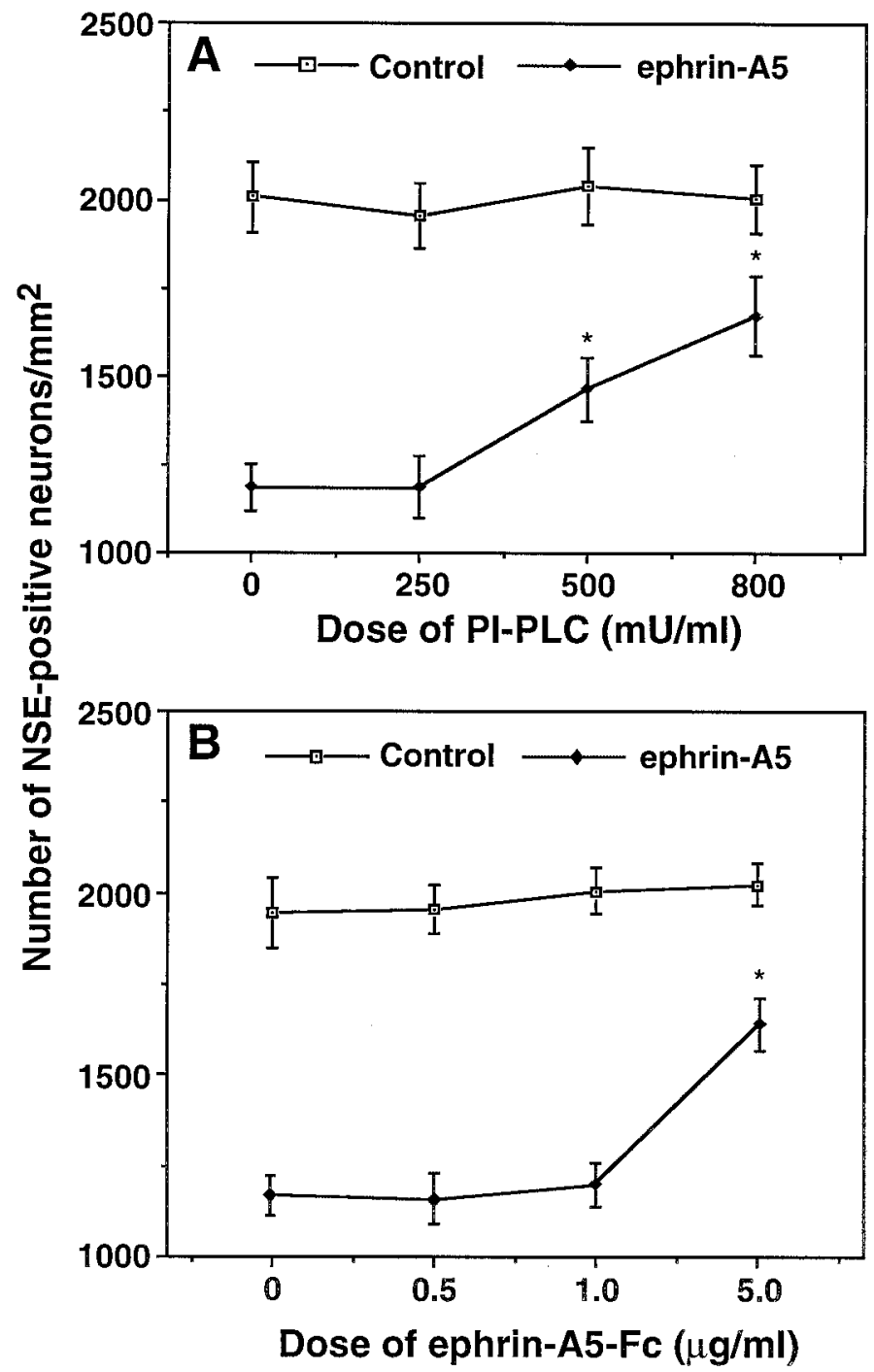

Figure 6. Induction of ventral spinal cord neuron loss is ephrindependent. Ventral E17 rat lumbar spinal neurons were cocultured with ephrin-expressing or control cells in the presence of various concentrations of PI-PLC $(A)$ or purified soluble ephrin-A5-Fc $(B)$. Data shown are the average numbers of neurons $/ \mathrm{mm}^{2} \pm$ SEM from three different assays. *Significant differences $(p<0.001$; ANOVA).

mediating the interactions between the dorsal and ventral spinal cord. According to the initial direction of axonal growth, ventral spinal cord interneurons can be classified into two major groups: circumferential cells and longitudinal cells (Yaginuma et al., 1993). Circumferential axons grow ventrally first and then cross the midline to join the contralateral longitudinal pathway (SilosSantiago and Snider, 1992, 1994; Yaginuma et al., 1994). The ventroward extension has been shown to be mediated by chemoattractive factors, the netrins, expressed in a dorsoventral gradient in the ventral spinal cord with the highest levels in the floor plate (Colamarino and Tessier-Lavigne, 1995). The longitudinal cells project either rostrally or caudally along an ipsilateral longitudinal pathway (Silos-Santiago and Snider, 1992, 1994; Yaginuma et al., 1994). Both types of neurons do not project significantly to the dorsal spinal cord. The spatial distribution of the Eph receptors and ligand in the spinal cord is consistent with a role in the prevention of dorsoward projection by the ventral spinal neurons, although this remains to be demonstrated in vivo.
It is also possible that the Eph receptors and ephrins may have other functions in the developing spinal cord. For example, they may be involved in the segregation of dorsal and ventral spinal neurons during early development or in the segregation of different groups of motor neurons, as suggested by the presence of ephrin-A5 in subpopulations of the motor neurons at the upper limb level in the E12 and E13 mouse embryos (Flenniken et al., 1996). Ephrins and their receptors have been shown to be expressed alternatively in even and odd number rhombomeres and to be critical for the maintenance of rhombomere boundaries ( $\mathrm{Xu}$ et al., 1995; Durbin et al., 1998). Further studies using ephrin-A5 and EphA5 knock-out animals are necessary to differentiate these different possibilities.

\section{Inhibition of ventral neurite outgrowth by ephrin-A5}

In this study, we showed that the neuritic growth of ventral spinal cord neurons was reduced severely by ephrin-A5. These observations are consistent with several previous observations that ephrins are inhibitory and/or repulsive for the axonal growth of many different neuronal populations (Drescher et al., 1995; Donoghue et al., 1996; Gao et al., 1996, 1998, 1999; Nakamoto et al., 1996; Monschau et al., 1997; Ohta et al., 1997; Wang and Anderson, 1997). The reduction of neuritic length shown here is likely attributable to axon retraction or degeneration, similar to that observed in hippocampal neurons (Gao et al., 1999).

A previous study showed that purified soluble ephrin-A1 promotes the survival and neurite outgrowth of spinal cord neurons (Magal et al., 1996). The positive effects by soluble ephrin-A1 may result from the inhibition of endogenous ligand/receptor interaction, because it has been shown that uncross-linked ephrins inhibit receptor function (Gale et al., 1996; Yue et al., 1999). Consistent with this interpretation, uncross-linked soluble ephrin-A5-Fc also increased the length of neurites and the number of surviving ventral spinal neurons in this study, by reversing the negative effects of the membrane-anchored ligand. Thus, our observations here suggest that ephrin-A5 may regulate the formation of spinal cord neural circuitry by restricting the growth of the ventral spinal cord neurites.

\section{Ephrin-A5 and apoptosis of ventral spinal cord neurons}

We also observed that ephrin-A5 induced apoptosis of the ventral spinal neurons in vitro. There are two lines of evidence supporting this conclusion. First, the numbers of neurons were reduced significantly by functional ephrin-A5, both in the coculture assay and in the assay, using cross-linked purified ligand. Second, ephrin-A5 significantly increased the number of TUNELpositive cells in both assays. The physiological significance of the ephrin-induced apoptosis in vitro is not clear at the present. There are at least two interpretations. (1) Cell death is an indirect effect caused by the gradual loss of adhesion of the ventral neurons in the presence of ephrins. Although this possibility cannot be ruled out, we think it is not very likely, because ephrin-A2, -A3, and -A5 all restrict hippocampal neurite outgrowth but do not affect cell adhesion to the substrate (Gao et al., 1996, 1999). (2) Ephrininduced apoptosis contributes to the elimination of neurons with mistargeted axons or neurons migrated to the wrong position during spinal cord morphogenesis. A critical process during spinal cord development is that significant numbers of neurons generated in early embryogenesis die via apoptosis in later stages (Oppenheim, 1991). In rat embryonic spinal cord, large numbers of ventral interneurons die at approximately E16 (Lawson et al., 

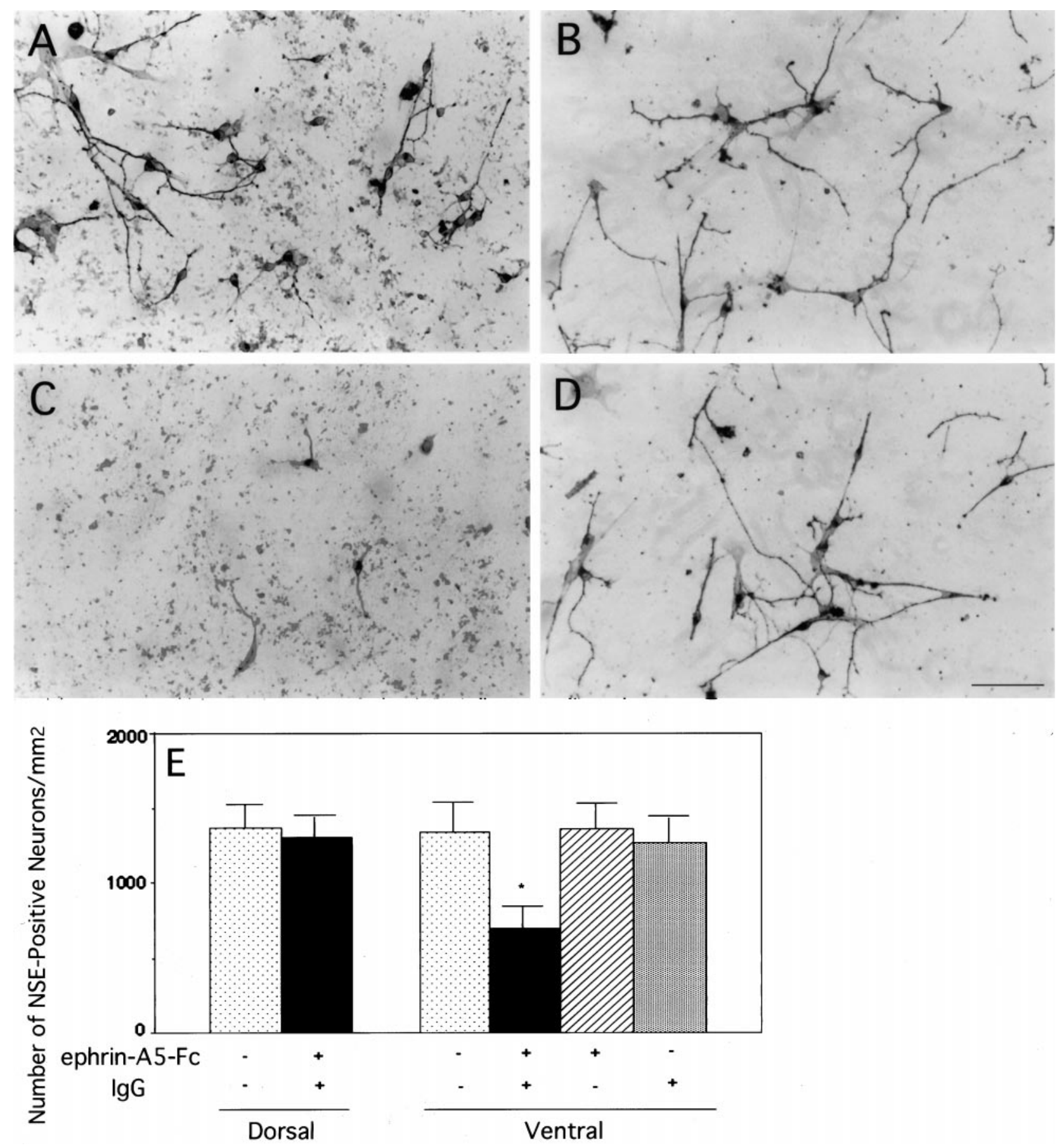

Figure 7. Selective inhibition of neurite outgrowth and cell survival of the ventral spinal cord neurons by cross-linked purified ephrin-A5-Fc. Dorsal or ventral E17 rat lumbar spinal cord neurons were cultured in tissue culture wells coated with uncross-linked purified ephrin-A5 alone, anti-human IgG alone, purified ephrin-A5-Fc cross-linked with anti-human IgG, or neither of these two proteins (see Materials and Methods for details). $A, B$, Photomicrographs of dorsal spinal cord neurons cultured in tissue culture wells coated with cross-linked or uncross-linked ephrin-A5, respectively. $C, D$, Photomicrographs of ventral spinal cord neurons cultured in tissue culture wells coated with cross-linked or uncross-linked ephrin-A5, respectively. Scale bar in $D$, $40 \mu$ m. $E$, Quantitative analysis of the effects of ephrin-A5-Fc on the survival of cultured spinal cord neurons. Data shown are the average numbers of neurons/mm ${ }^{2} \pm$ SEM. The difference of cell density of ventral spinal cord neurons in cross-linked ephrin-A5 or control cultures is significant $(* p<0.001 ;$ ANOVA). No significant decrease was observed in the number of ventral spinal cord neurons cultured with only soluble ephrin-A5-Fc or anti-human IgG alone. In addition, there was no significant difference in the number of dorsal spinal cord neurons cultured in wells coated with cross-linked ephrin-A5-Fc or with poly-D-lysine/laminin alone. Neurons are identified by immunohistochemistry with the use of anti-tau-1 monoclonal antibody.

1997). The time of EphA5 expression in the ventral interneurons overlaps with that of interneuron cell death. In addition, the spatial distribution of the dying interneurons overlaps with that of EphA5 expression in the ventral spinal cord during this time
(Lawson et al., 1997) (see Fig. 1). Apoptosis in the nervous system has been postulated to regulate the number of neurons in a population and/or the precision of their connections as well as to remove erroneous projections (Cowan et al., 1984; Clarke, 1985; 

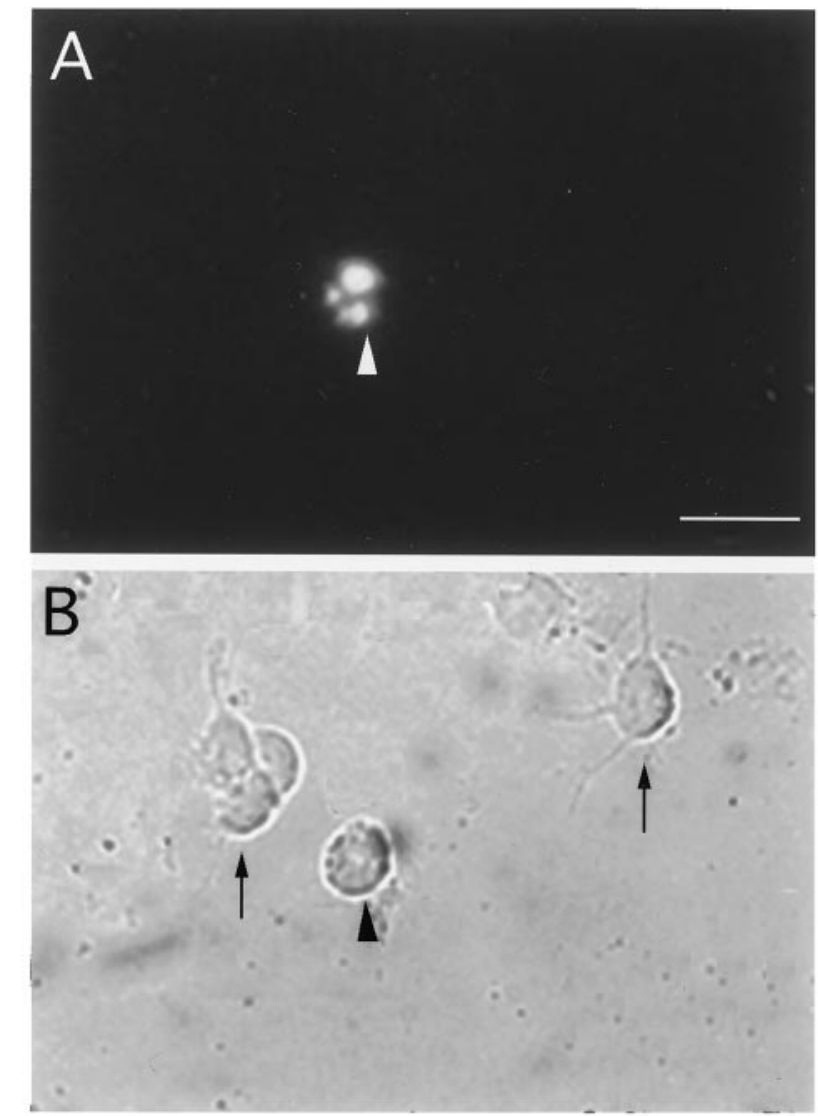

N

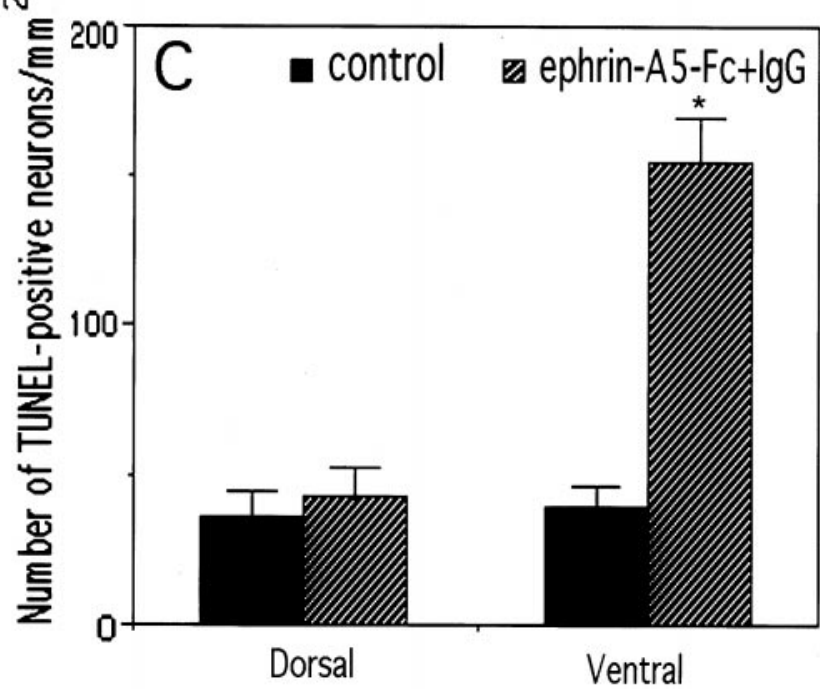

Figure 8. Induction of apoptosis of ventral spinal cord neurons by crosslinked ephrin-A5-Fc. Dorsal or ventral E17 rat lumbar spinal cord neurons were cultured in tissue culture wells coated with cross-linked or uncross-linked ephrin-A5-Fc. After $30 \mathrm{hr}$ of culture the cells were analyzed with the TUNEL assay to identify apoptotic neurons. $A, B$, Fluorescent and bright-field microphotographs of TUNEL-stained ventral spinal cord neurons (indicated by an arrowhead) in cross-linked ephrin-A5 culture. The TUNEL staining was specific, because live cells (indicated by arrows in $B$ ) were negative. Scale bar in $A, 40 \mu \mathrm{m}$. $C$, Quantitative analysis of dorsal and ventral spinal cord neurons labeled by the TUNEL assay. The difference in the number of TUNEL-positive cells in the ventral spinal cord culture in the presence of cross-linked or uncross-linked ephrin-A5-Fc is significant ( ${ }^{*} p<0.001$; Student's $t$ test). Dorsal spinal cord neurons showed a low background staining. Data shown are the average numbers of neurons $/ \mathrm{mm}^{2} \pm$ SEM labeled by TUNEL staining from five assays.
Catsicas et al., 1987; Purves, 1988; Oppenheim, 1991). Our results are consistent with a role of the Eph family in inducing cell death in spinal cord morphogenesis or the elaboration of neural circuits. Further studies using ephrin or Eph knock-out mice are necessary to understand the significance of these observations.

\section{REFERENCES}

Bernhardt RR, Chitnis AB, Lindamer L, Kuwada JA (1990) Identification of spinal neurons in the embryonic and larval zebrafish. J Comp Neurol 302:603-616.

Catsicas S, Thanos S, Clarke P (1987) Major role for neuronal death during brain development: refinement of topographic connections. Proc Natl Acad Sci USA 84:8165-8168.

Cheng H-J, Nakamoto M, Bergemann AD, Flanagan JG (1995) Complementary gradients in expression and binding of ELF-1 and Mek4 in development of the topographic retinotectal projection map. Cell 82:371-381.

Ciossek T, Monschau B, Kremoser C, Loschinger J, Lang S, Muller BK, Bonhoeffer F, Drescher U (1998) Eph receptor-ligand interactions are necessary for guidance of retinal ganglion cell axons in vitro. Eur $\mathbf{J}$ Neurosci 10:1574-1580.

Clarke PGH (1985) Neuronal death during development in the isthmooptic nucleus of the chick: sustaining role of afferents from the tectum. J Comp Neurol 243:365-379.

Colamarino SA, Tessier-Lavigne M (1995) The role of the floor plate in axon guidance. Annu Rev Neurosci 18:497-529.

Cowan WM, Fawcett JW, O'Leary DD, Stanfield BB (1984) Regressive events in neurogenesis. Science 225:1258-1265.

Davis S, Gale NW, Aldrich TH, Maisonpierre PC, Lhotak V, Pawson T, Goldfarb M, Yancopoulos GD (1994) Ligands for EPH-related receptor tyrosine kinases that require membrane attachment or clustering for activity. Science 266:816-819.

Donoghue MJ, Lewis RM, Merlie JP, Sanes JR (1996) The Eph kinase ligand AL-1 is expressed by rostral muscles and inhibits outgrowth from caudal neurons. Mol Cell Neurosci 8:185-198.

Drescher U (1997) The Eph family in the patterning of neural development. Curr Biol 7:799-807.

Drescher U, Kremoser C, Handwerker C, Loschinger J, Noda M, Bonhoeffer F (1995) In vitro guidance of retinal ganglion cell axons by RAGS, a $25 \mathrm{kDa}$ tectal protein related to ligands for Eph receptor tyrosine kinases. Cell 82:359-370.

Durbin L, Brennan C, Shiomi K, Cooke J, Barrios A, Shanmugalingam S, Guthrie B, Lindberg R, Holder N (1998) Eph signaling is required for segmentation and differentiation of the somites. Genes Dev 12:3096-3109.

Flanagan JG, Leder P (1990) The kit ligand: a cell surface molecule altered in steel mutant fibroblasts. Cell 63:185-194.

Flanagan JG, Vanderhaeghen P (1998) The ephrins and Eph receptors in neural development. Annu Rev Neurosci 21:309-345.

Flenniken AM, Gale NW, Yancopoulos GD, Wilkinson DG (1996) Distinct and overlapping expression patterns of ligands and Eph-related receptor tyrosine kinases during mouse embryogenesis. Dev Biol 179:382-401.

Friedman GC, O'Leary DDM (1996) Eph receptor tyrosine kinases and their ligands in neural development. Curr Opin Neurobiol 6:127-133.

Gale NW, Holland SJ, Valenzuela DM, Flenniken A, Pan L, Ryan TE, Henkemeyer M, Strebhardt K, Hirai H, Wilkinson DG, Pawson T, Davis S, Yancopoulos GD (1996) Eph receptors and ligands comprise two major specificity subclasses and are reciprocally compartmentalized during embryogenesis. Neuron 17:9-19.

Gao P-P, Zhang J-H, Yokoyama M, Racey B, Dreyfus CF, Black IB, Zhou R (1996) Regulation of topographic projection in the brain: Elf-1 in the hippocamposeptal system. Proc Natl Acad Sci USA 93:11161-11166.

Gao P-P, Yue Y, Zhang J-H, Cerretti DP, Levitt P, Zhou R (1998) Regulation of thalamic neurite outgrowth by the Eph ligand ephrin-A5: implications in the development of thalamocortical projections. Proc Natl Acad Sci USA 95:5329-5334.

Gao P-P, Yue Y, Cerretti DP, Dreyfus C, Zhou R (1999) Induction of axonal growth, branching, and degeneration by the Eph family ligands. Proc Natl Acad Sci USA 96:4073-4077.

Gavrieli Y, Sherman Y, Ben-Sasson SA (1992) Identification of programmed cell death in situ via specific labeling of nuclear DNA fragmentation. J Cell Biol 119:493-501. 
Harris WA, Holt CE (1995) From tags to RAGS: chemoaffinity finally has receptors and ligands. Neuron 15:241-244.

Kilpatrick TJ, Brown A, Lai C, Gassmann M, Goulding M, Lemke G (1996) Expression of the tyro4/mek4/cek4 gene specifically marks a subset of embryonic motor neurons and their muscle targets. Mol Cell Neurosci 7:62-74.

Lawson SJ, Davis HJ, Bennett JP, Lowrie MB (1997) Evidence that spinal interneurons undergo programmed cell death postnatally in the rat. Eur J Neurosci 9:794-799.

Magal E, Holash JA, Toso RJ, Chang D, Lindberg RA, Pasquale EB (1996) B61, a ligand for the Eck receptor protein-tyrosine kinase, exhibits neurotrophic activity in cultures of rat spinal cord neurons. J Neurosci Res 43:735-744.

Monschau B, Kremoser C, Ohta K, Tanaka H, Kaneko T, Yamada T, Handwerker C, Hornberger MR, Loschinger J, Pasquale EB, Siever DA, Verderame MF, Muller BK, Bonhoeffer F, Drescher U (1997) Shared and distinct functions of RAGS and ELF-1 in guiding retinal axons. EMBO J 16:1258-1267.

Nakamoto M, Cheng H-J, Friedman GC, McLaughlin T, Hansen MJ, Yoon CH, O'Leary DDM, Flanagan JG (1996) Topographically specific effects of ELF-1 on retinal axon guidance in vitro and retinal axon mapping in vivo. Cell 86:755-766.

Ohta K, Nakamura M, Hirokawa K, Tanaka S, Iwama A, Suda T, Ando M, Tanaka H (1996) The receptor tyrosine kinase, Cek8, is transiently expressed on subtypes of motoneurons in the spinal cord during development. Mech Dev 54:59-69.

Ohta K, Iwamasa H, Drescher U, Terasaki H, Tanaka H (1997) The inhibitory effect on neurite outgrowth of motoneurons exerted by the ligands ELF-1 and RAGS. Mech Dev 64:127-135.

Oppenheim RW (1991) Cell death during development of the nervous system. Annu Rev Neurosci 14:453-501.

Orioli D, Klein R (1997) The Eph receptor family: axonal guidance by contact repulsion. Trends Genet 13:354-359.

Purves D (1988) Body and brain: a trophic theory of neuronal connections. Cambridge, MA: Harvard UP.

Silos-Santiago I, Snider WD (1992) Development of commissural neurons in the embryonic rat spinal cord. J Comp Neurol 325:514-526.

Silos-Santiago I, Snider WD (1994) Development of interneurons with ipsilateral projections in embryonic rat spinal cord. J Comp Neurol 342:221-231.

Stein E, Lane AA, Cerretti DP, Schoecklmann HO, Schroff AD, Van Etten RL, Daniel TO (1998) Eph receptors discriminate specific ligand oligomers to determine alternative signaling complexes, attachment, and assembly responses. Genes Dev 12:667-678.

Tessier-Lavigne M (1995) Eph receptor tyrosine kinases, axon repulsion, and the development of topographic maps. Cell 82:345-348.

Wang H, Anderson DJ (1997) Eph family transmembrane ligands can mediate repulsive guidance of trunk neural crest migration and motor axon outgrowth. Neuron 18:383-396.

Xu Q, Alldus G, Holder N, Wilkinson DG (1995) Expression of truncated Sek-1 receptor tyrosine kinase disrupts the segmental restriction of gene expression in the Xenopus and zebrafish hindbrain. Development 121:4005-4016.

Yaginuma H, Shiga T, Oppenheim RD (1993) Mechanisms of axonal guidance used by interneurons in the chick embryo spinal cord. Perspect Dev Neurobiol 1:205-215.

Yaginuma H, Shiga T, Oppenheim RD (1994) Early developmental patterns and mechanisms of axonal guidance of spinal interneurons in the chick embryo spinal cord. Prog Neurobiol 44:249-278.

Yue Y, Widmer DAJ, Halladay AK, Cerretti DP, Wagner GC, Dreyer J-L, Zhou R (1999) Specification of distinct dopaminergic neural pathways: roles of the Eph family receptor Eph-B1 and ligand ephrinB2. J Neurosci 19:2090-2101.

Zhang J-H, Cerretti DP, Yu T, Flanagan JG, Zhou R (1996) Detection of ligands in regions anatomically connected to neurons expressing the Eph receptor Bsk: potential roles in neuron-target interaction. J Neurosci 16:7182-7192.

Zhang J-H, Pimenta AF, Levitt P, Zhou R (1997) Dynamic expression suggests multiple roles of the Eph family receptor brain-specific kinase (Bsk) during mouse neurogenesis. Mol Brain Res 47:202-214.

Zhou R (1998) The Eph family receptors and ligands. Pharmacol Ther 77:151-181.

Zhou R, Copeland TD, Kromer LF, Schulz NT (1994) Isolation and characterization of Bsk, a growth factor receptor-like kinase associated with the limbic system. J Neurosci Res 37:129-143. 